\title{
CLIMATE CHANGE IMPACTS ON CROP YIELDS
}

Timothy S. Thomas, Paul Dorosh, and Richard Robertson

\section{Introduction}

It is commonly thought that climate change is likely to have major effects on Ethiopian agriculture and the country's overall development over the next fifty years and beyond. Indeed, each of the 32 major climate change models used in our analysis indicate a high probability of significant increases in average world temperatures by 2055 as well as an increase in median temperatures in Ethiopia. The prognosis for rainfall in Ethiopia is much less certain, although on average the simulation models suggest a relatively small increase in rainfall for the country overall. Moreover, there is a growing consensus that climate variability will increase in all regions of the world (IPCC 2018).

Earlier studies of the likely effects of climate change in Ethiopia point to both positive and negative effects. Studies using hydrological models to assess the potential effects of climate change on water flow in various basins in Ethiopia (Dile, Berndtsson, and Setegn 2013; Wagena et al. 2016) generally suggest significant increases in water availability with potential benefits for irrigation as well as increases in variability and flooding (see also Taye, Willems, and Block 2015; Nawaz et al. 2010; Kim, Kaluarachchi, and Smakhtin 2008; Kim and Kaluarachchi 2009). ${ }^{1}$ Admassu et al. (2013) used a crop model linked to a multimarket model of supply and demand of agricultural commodities to project climate effects on key crops in Ethiopia between 2000 and 2050. Based on output of four climate models, their analysis shows yield gains of over 25 percent in much of the eastern highlands and north-central highlands, but large yield reductions and loss of areas suitable

1 In their analysis of the upper Blue Nile Basin for 2010-2100, Dile, Berndtsson, and Setegn (2013) find that climate change may result in an annual increase in flow volume for the Gilgel Abay River, benefiting local small-scale irrigation activities. Likewise, Wagena et al. (2016) used watershed models to analyze water flows in the highlands of the Blue Nile Basin for two periods (2041-2065 and 2075-2099) based on four climate scenarios from six climate models. Their results indicate that the Tana and Beles Basins will have large (22-27 percent) increases in mean annual flow, as well as 16 percent to 19 percent increases in sediment concentrations, with potentially large net benefits for hydropower generation. 
for growing maize in the eastern and southwestern parts of central Ethiopia. ${ }^{2}$ Robinson, Willenbockel, and Strzepek (2012) included general equilibrium effects in their analysis of potential effects on water flows, crops, infrastructure, and economic output, concluding that, in the absence of adaptation investments, Ethiopia's GDP in 2050 would be up to 10 percent below the counterfactual baseline of no climate change. ${ }^{3}$

This chapter presents a further analysis of the potential effects of projected climate change scenarios for cereal crop yields in Ethiopia in 2035, 2055, and 2085. The methodology used in determining the direct effect of climate on crop yields (described in detail below) is similar to that of Admassu et al. (2013) but differs in using agroecological zones more closely corresponding to cropping patterns in Ethiopia as well as by drawing on the results of a wider array of climate models. ${ }^{4}$ In particular, we use coefficients from regressions of simulated yields from a crop simulation model, the Decision Support System for Agrotechnology Transfer (DSSAT) crop systems model, with climate variables as explanatory variables. In the discussion of our simulation results in this chapter, we provide an explicit comparison with the results of Admassu et al. (2013).

First we summarize the results of the major climate models for rainfall and temperature across six main agroecological zones in Ethiopia. Thereafter, we present results of the crop yield models for three of the major cereal crops in Ethiopia: wheat, maize, and sorghum. (Unfortunately, no crop model is available for teff.) We then construct long-term yield growth trends consistent with historical yield growth and yield gaps between Ethiopia and comparator countries in Africa south of the Sahara. The last part of the chapter presents a brief summary and conclusions.

2 In these simulations maize yields rise through 2020 before leveling off between 2020 and 2050. Rainfed wheat yields generally decline in response to climate change, with one of the climate models Admassu et al. (2013) used showing large losses. The crop model results for sorghum are very similar to those for maize.

3 Robinson, Willenbockel, and Strzepek (2012) used a system of hydrology, crop, road, and other models to simulate the possible effects of changes in precipitation and temperature as reflected in projections from four of 22 global climate models available at the time of the study. Unlike the main analysis here, which is based on the average results from a set of 31 global climate models, the Robinson, Willenbockel, and Strzepek (2012) analysis was designed to provide an estimate of the range of outcomes, so was based on four extreme projections: the wettest and driest projections on a global scale, and the wettest and driest projections for Ethiopia. Agricultural GDP is highest under the driest global climate projection but falls in other projections, in part due to damage from extreme floods in some years.

4 Also, unlike Admassu et al. (2013), our modeling approach does not include effects of changes in incomes and prices. 


\section{Climate Change Scenarios: Rainfall and Temperature Projections}

Our analysis draws on temperature and rainfall outcomes from simulations of 32 downscaled global climate models for 2035, 2055, and 2085 (Ramirez and Jarvis 2008). ${ }^{5}$ We use the simulated monthly means of rainfall and temperature by 5 arc minute grid cells (pixels equivalent in size to about 9 kilometers $\times 9$ kilometers at the equator) from each global climate model. We use the absolute deviations from the mean temperature and rainfall from each of the 31 years (1980 to 2010) from the AgMERRA database (Ruane, Goldberg, and Chryssanthacopoulos 2015) to generate a set of $992(32 \times 31)$ simulated temperature and rainfall outcomes for each of the grid cells that encompass Ethiopia for each of the three simulation years $\left(2035,2055\right.$, and 2085). ${ }^{6} \mathrm{We}$ use climate models to tell us how much the mean of the distribution should change under climate change, and we use historical weather to give plausible variation to those means, with the purpose of simulating a distribution of what future weather might look like.

Thus, for global climate model $m$, grid cell $i$, climate realization $t$ and simulation year $\mathrm{T}(=2035,2055$, or 2085$)$, mean rainfall (or temperature) $R$, is calculated as:

$$
R(m, i, t, T)=r(m, i, T)+e(i, t),
$$

where $r(m, i, T)=$ mean (or median) simulated value of rainfall (or temperature) from model $m$ for grid cell $i$ and year $T$, and $e(i, t)=$ deviation from mean rainfall (or temperature) from historic climate realization from 1980 through $2010(t=1,31)$.

Table 4.1 presents the results for rainfall and temperature for the six agroecological zones in Ethiopia defined in Schmidt and Thomas (2018). As a base for comparison, we use the average climate conditions for the 1960-1990 period from WorldClim (v. 1.4, Hijmans et al. 2005). Taken together, the outputs from these 32 climate models suggest that Ethiopia will likely have

5 Throughout this chapter, "1975" may be used as a shorthand notation for averages for the 1960 1990 period; "2013" for averages for the 2012-2015 period; "2035" for averages for the 20202049 period; " 2055 " for averages for the 2040-2060 period; and " 2085 " for averages for the 2070-2099 period. The latter three periods are based on Ramirez-Villegas and Jarvis (2010).

6 Note that this procedure implicitly assumes that the distribution of percentage deviations from mean temperature and rainfall realizations from the 1980-2010 period remains the same for future periods. 


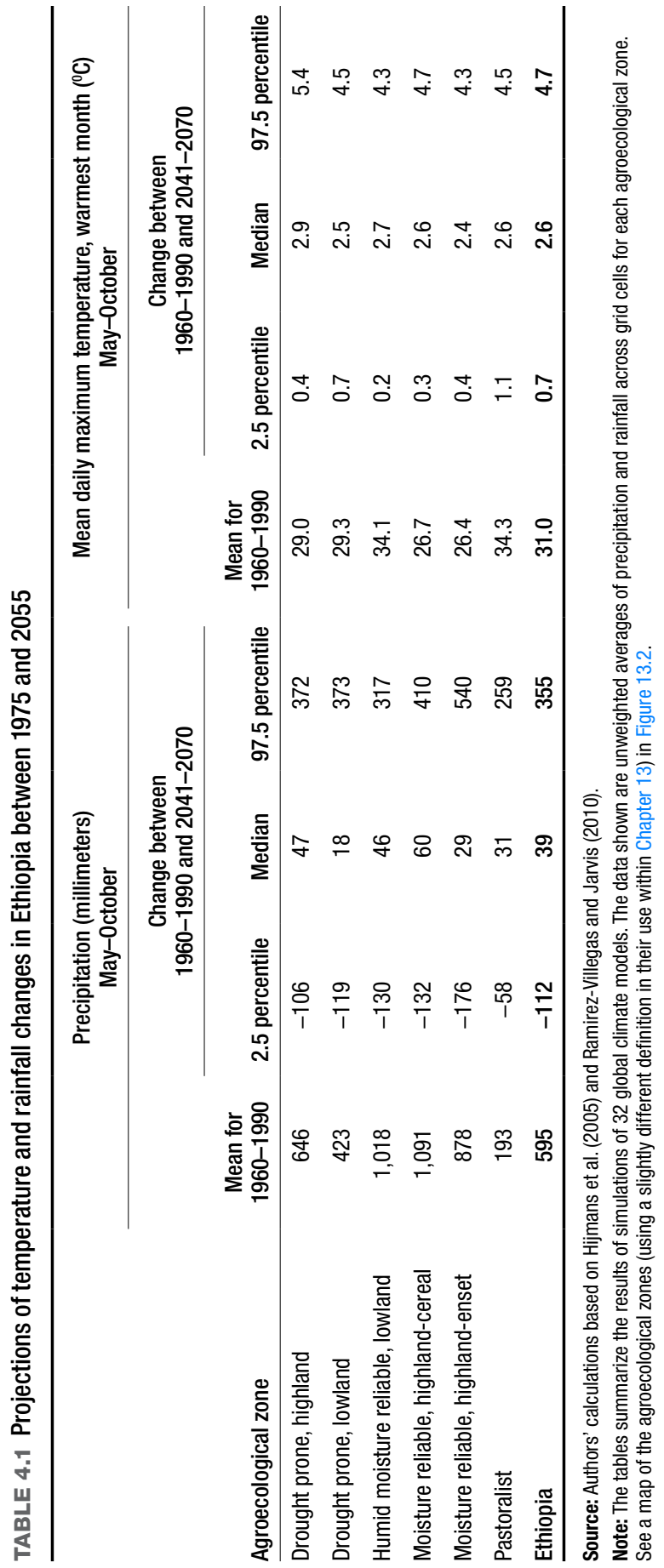


a moderate increase in rainfall in all agroecologies in the main growing season (May-October), with a median increase in precipitation of 39 millimeters above the mean precipitation of 595 millimeters in the $1960-1990$ period (Figure 4.1). The mean daily maximum temperatures of the warmest month in the main growing season (May-October), however, are likely to be considerably higher than in the base period, with a median increase of 2.6 degrees $\mathrm{C}$. This increase is approximately equal to the median temperature increase value for eastern Africa, but less than the global median temperature increase.

The largest absolute increases in mean daily maximum temperatures are expected to be in the drought-prone highlands-a median increase of 2.9 degrees C, from 29.0 degrees $C$ in the $1960-1990$ period to 31.9 degrees $C$ in the 2041-2070 period. Likewise, this agroecological zone has the largest extreme temperature gains, with an increase of 5.4 degrees $C$ in the top 2.5 percent of the temperature distribution across the sample of model simulations (Figure 4.2).

\section{Potential Effects of Climate Change on Maize, Wheat, and Sorghum Yields}

To estimate the effects of climate change on crop yields, we employ results of simulations using the Decision Support System for Agrotechnology Transfer (DSSAT) suite of crop models. ${ }^{7}$ We use yields calculated by DSSAT along with the corresponding weather input into those models to estimate parameters in a regression that describe how weather variables and other important agronomic variables influence yield. We then take these regression parameter estimates and use them to estimate the effects of simulated climate change outcomes on yields.

Yield effects in DSSAT are calculated for each 9 kilometers by 9 kilometers grid cell in a geographic grid under purely rainfed conditions. In our work with DSSAT we use monthly weather inputs that DSSAT converts to daily weather using an internal weather simulator. For this exercise we feed into DSSAT rainfall and temperature outcomes from the HadGEM2_ES global climate model (Collins et al. 2011; Martin et al. 2011) and under the RCP8.5 high emissions scenario for the 2041-2070 period and for the 2071-2099 period as well as for historical climate data from 1960 to 1990. Doing so gives

7 DSSAT is a suite of single crop models (Hoogenboom et al. 2012; Jones et al. 2003). Yields are estimated using site-specific weather data during the growing season, soil data, and management practices. 
FIGURE 4.1 Simulated rainfall in 2055 by agroecological zone in Ethiopia (millimeters)

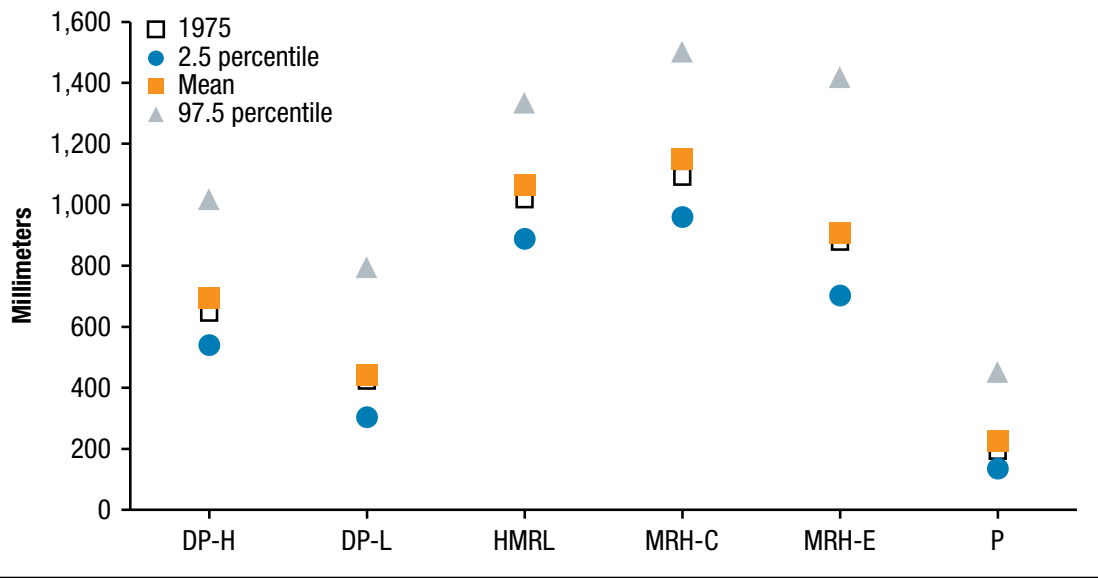

Source: Authors' calculations from climate model simulations.

Note: DP-H = drought prone, highland; DP-L = drought prone, lowland; HMRL = humid moisture reliable, lowland; MRH-C $=$ moisture reliable, highland-cereal; $\mathrm{MRH}-\mathrm{E}=$ moisture reliable, highland-enset; $\mathrm{P}=$ pastoralist. The year 2055 is the middle year of the 2041-2070 period, on which the climate data are based.

FIGURE 4.2 Simulated temperature in 2055 by agroecological zone in Ethiopia (degrees Celsius)

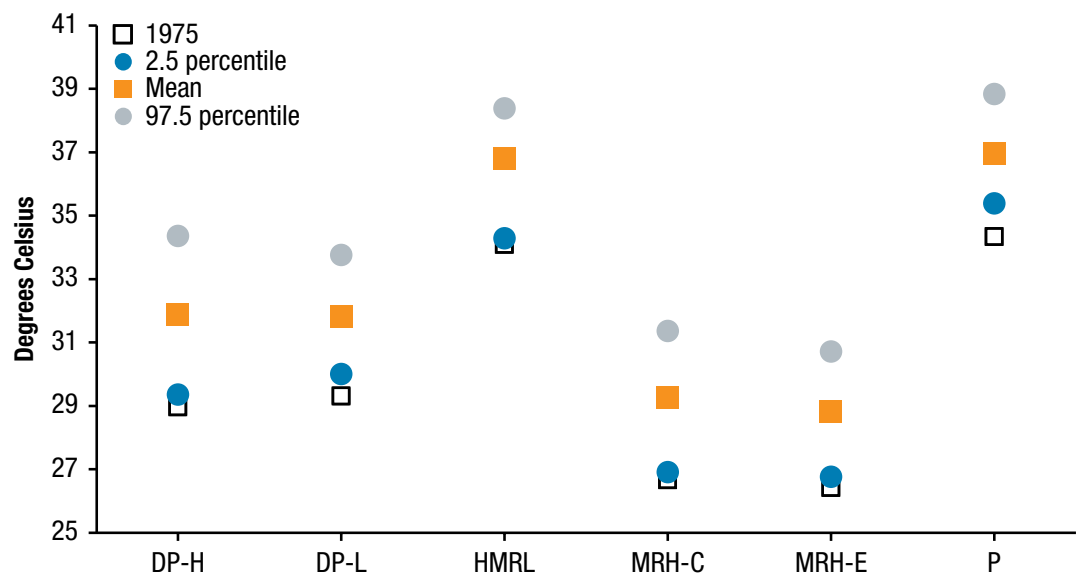

Source: Authors' calculations from climate model simulations.

Note: DP-H = drought prone, highland; DP-L = drought prone, lowland; HMRL = humid moisture reliable, lowland; MRH-C $=$ moisture reliable, highland - cereal; $\mathrm{MRH}-\mathrm{E}=$ moisture reliable, highland - enset; $\mathrm{P}=$ pastoralist. The year 2055 is the middle year of the 2041-2070 period, on which the climate data are based. 
us a wide range of values for the regression (ranging from no climate change to a very large climate change represented by the HadGEM2_ES model at the end of the century). ${ }^{8} \mathrm{~A}$ wide range of climate values helps us to ensure that the parameter estimates provide a good fit for feasible values spanning more than a century.

Using the output from the DSSAT model, the yield of $\operatorname{crop} c$ (wheat, sorghum, meher season maize, or belg season maize) planted on soil type $s$ in grid cell $i$ under model simulation $m s$ is estimated as follows:

$$
\begin{gathered}
\text { Yield }(c, i)=\mathrm{a}_{0}(c)+\mathrm{a}_{1}(\mathrm{c})^{*} \operatorname{elev}(\mathrm{i})+\mathrm{a}_{2}(\mathrm{c})^{*} \operatorname{elev}(\mathrm{i})^{2}+\mathrm{a}_{3}(\mathrm{c})^{*} \mathrm{~N}(\mathrm{i})+\mathrm{a}_{4}(\mathrm{c})^{*} \mathrm{~N}(\mathrm{i})^{2} \\
+\sum_{s=0}^{12}\left[\mathrm{a}_{5 \mathrm{~s}}(\mathrm{c})^{*} \mathrm{D}(\mathrm{s}, \mathrm{i})\right] \\
+\sum_{m=0}^{3}\left[\beta_{1 m}(c)^{*} \text { rain }(i, m)+\beta_{2 m}(c)^{*} \operatorname{rain}(i, m)^{2}+\beta_{3 m}(c)^{*} \operatorname{rain}(i, m)^{3}\right. \\
+\beta_{4 m}(c)^{*} \operatorname{temp}(i, m, m s)+\beta_{5 m}(c)^{*} \operatorname{temp}(i, m, m s)^{2}+\beta_{6 m}(c)^{*} \operatorname{temp}(i, m)^{3} \\
+\beta_{7 m}(c)^{*} \text { rain }(i, m)^{*} \operatorname{temp}(i, m)+\beta_{8 m}(c)^{*} \text { rain }(i, m)^{* *} \operatorname{temp}(i, m) \\
\left.+\beta_{9 m}(c)^{*} \operatorname{temp}(i, m)^{2 *} \operatorname{rain}(i, m)\right]+e(c, i),
\end{gathered}
$$

where rain $(i, m, m s)$ and temp $(i, m, m s)$ are total rainfall and mean daily maximum temperature, respectively, for grid cell $i$ and model simulation $m s ; m$ indexes the month during the growing season (with 0 being the planting month, 1 the month after the planting month, and so on); elev is the elevation of grid cell $i ; N$ is the starting nitrogen level for the soil in grid cell $i$; and $D(s, i)$ is a categorical value of 1 if the soil in grid cell $i$ is of type $s$ and 0 otherwise.' Parameters from this regression are then used to estimate yields for each crop for each 9 kilometer by 9 kilometer grid cell across Ethiopia using the rainfall and temperature outcomes from all 32 global climate models for each of 31 weather realizations.

For each pixel and crop, the DSSAT algorithm searches for the planting month that gives the highest yield based on the prediction from the regression, with the constraint that the planting month has to align with those recognized as feasible by agronomic professionals that work with Ethiopian agriculture.

Average yield changes for each of Ethiopia's six agroecological zones are calculated using weights from the spatially disaggregated estimates of area

8 Note that the yield calculations ignore possible carbon dioxide fertilization effects.

9 Because more spatially disaggregated data are not available, we assume that the soil type, rainfall, and temperature are uniform within each grid cell. 
cultivated for each crop from IFPRI's Spatial Production Allocation Model (SPAM) (You, Wood, and Wood-Sichra 2006; You et al. 2014).

\section{Implications of Climate Change on Crop Yields}

Overall, the simulated net effects of increases in average rainfall and higher average temperatures are relatively small. Simulated maize yields are higher on average in the climate change simulations, with average yields 1.2 percent and 4.2 percent higher than 2013 yields in 2035 and 2085, respectively (Table 4.2; Figure 4.3; Figure 4.4). Average wheat yields are only 0.3 percent lower in 2035 than in 2013, and only 1.1 percent and 2.7 percent lower by 2055 and 2085, respectively, than in 2013 (Table 4.2; Figure 4.3; Figure 4.5). Sorghum

TABLE 4.2 Simulated crop yields in Ethiopia with climate change

\begin{tabular}{lcccc}
\hline Crop & 2013 & 2035 & 2055 & 2085 \\
\hline Maize & & & & \\
Yield: Climate change with no technical change (kilograms per hectare) & 3,372 & 3,414 & 3,460 & 3,515 \\
Climate change effect, relative to $2013(\%)$ & n.a. & 1.2 & 2.6 & 4.2 \\
Yield: Technical change only (kilograms per hectare) & 3,372 & 4,644 & 6,255 & 9,777 \\
Cumulative technical change, relative to 2013 (\%) & n.a. & 38.8 & 86.9 & 192.1 \\
Yield: Technical change with climate change (kilograms per hectare) & 3,372 & 4,702 & 6,418 & 10,191 \\
Cumulative technical change with climate change (\%) & n.a. & 40.5 & 91.8 & 204.5 \\
Wheat & & & & \\
Yield: Climate change with no technical change (kilograms per hectare) & 2,475 & 2,467 & 2,447 & 2,409 \\
Climate change effect, relative to 2013 (\%) & n.a. & -0.3 & -1.1 & -2.7 \\
Yield: Technical change only (kilograms per hectare) & 2,475 & 3,065 & 3,740 & 5,041 \\
Cumulative technical change, relative to 2013 (\%) & n.a. & 23.9 & 51.1 & 103.7 \\
Yield: Technical change with climate change (kilograms per hectare) & 2,475 & 3,056 & 3,698 & 4,908 \\
Cumulative technical change with climate change (\%) & n.a. & 23.5 & 49.4 & 98.3 \\
Sorghum & & & & \\
Yield: Climate change with no technical change (kilograms per hectare) & 2,336 & 2,350 & 2,349 & 2,314 \\
Climate change effect, relative to 2013 (\%) & n.a. & 0.6 & 0.6 & -0.9 \\
Yield: Technical change only (kilograms per hectare) & 2,336 & 2,893 & 3,530 & 4,758 \\
Cumulative technical change, relative to 2013 (\%) & n.a. & 23.9 & 51.1 & 103.7 \\
Yield: Technical change with climate change (kilograms per hectare) & 2,336 & 2,911 & 3,550 & 4,714 \\
Cumulative technical change with climate change (\%) & n.a. & 24.6 & 52.0 & 101.8 \\
\hline
\end{tabular}

Source: Authors' calculations from model simulations.

Note: n.a. = not applicable

a. Based on average of actual yields for 2012 to 2015 (FA0 2019) and percentage changes from climate model simulations.

b. Using assumed yield annual growth rates (maize 1.5 percent, wheat 1.0 percent, sorghum 1.0 percent). 
yields in 2035 and 2055 are 0.6 percent higher than in 2013; by 2085, however, sorghum yields are 0.9 percent lower than in 2013 (Table 4.2; Figure 4.3; Figure 4.6).

Moreover, the simulated effects of climate change on yields vary somewhat across regions. For maize, median maize yields in the three highland

FIGURE 4.3 Simulated climate change impacts on crop yields in Ethiopia relative to 2013 yields (\%)

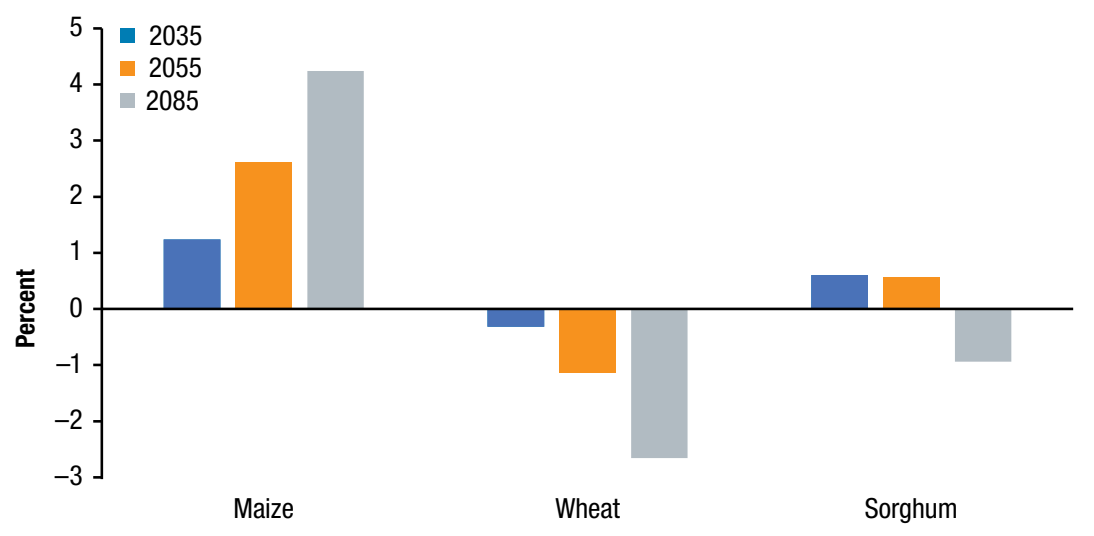

Source: Authors' calculations from model simulations.

FIGURE 4.4 Simulated climate change impacts on maize yields in Ethiopia, 2015-2085

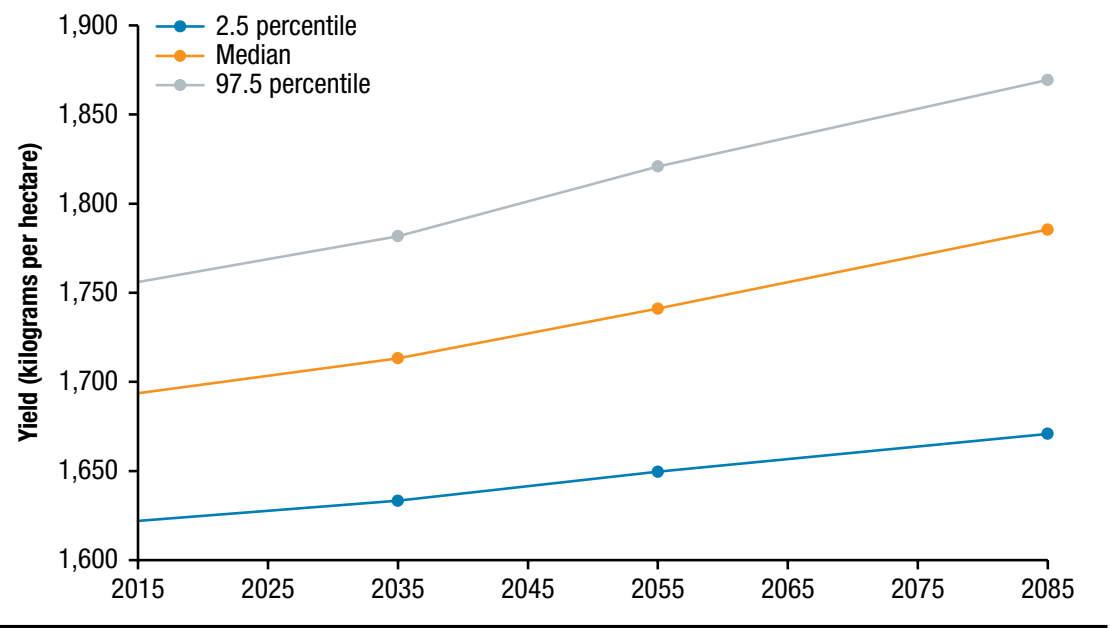

Source: Authors' calculations. 
FIGURE 4.5 Simulated climate change impacts on wheat yields in Ethiopia, 2015-2085

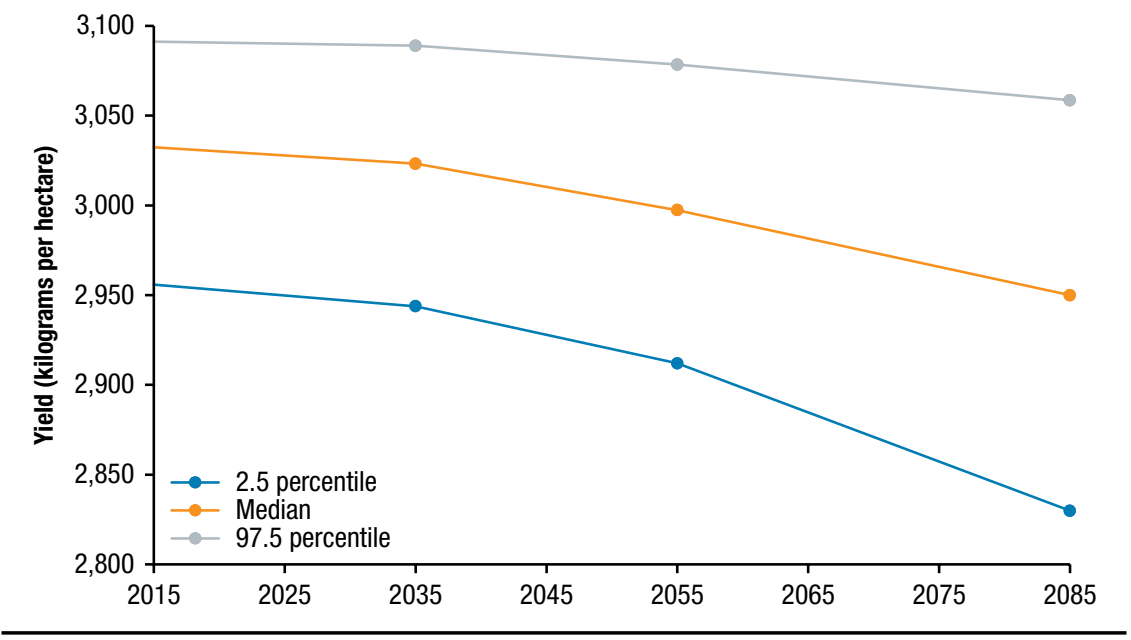

Source: Authors' calculations.

FIGURE 4.6 Simulated climate change impacts on sorghum yields in Ethiopia, 2015-2085

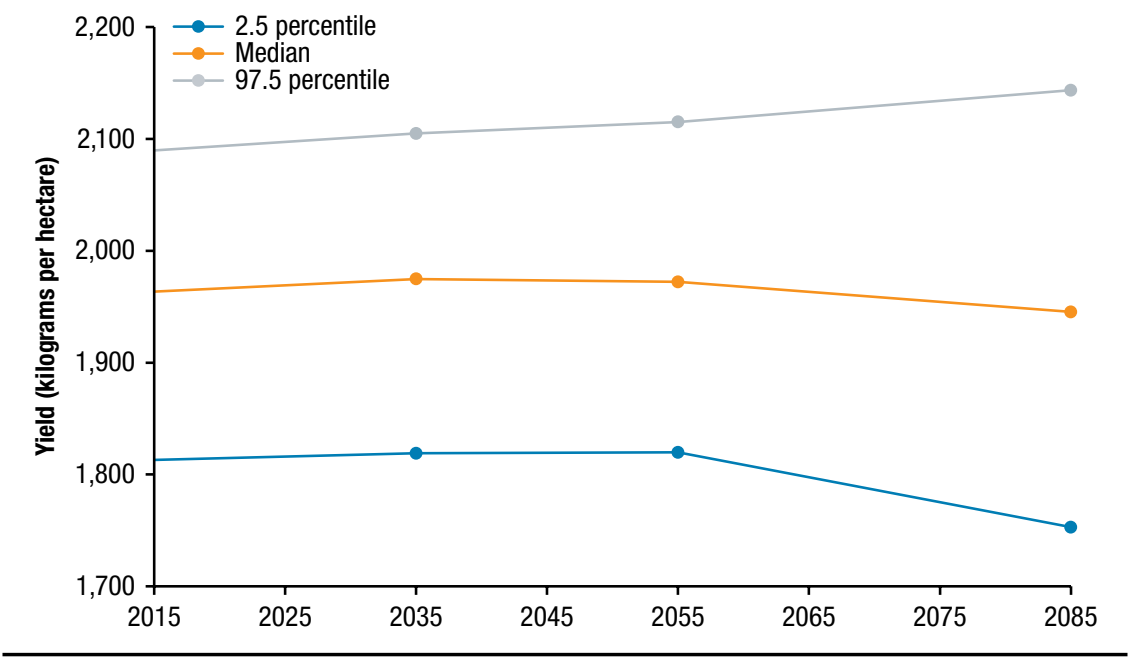

Source: Authors' calculations. 
TABLE 4.3 Simulated climate change effects on maize yields by agroecological zone in Ethiopia, relative to 2013 yields (\%)

\begin{tabular}{|c|c|c|c|c|c|c|c|}
\hline \multirow[b]{2}{*}{ Year } & \multicolumn{2}{|c|}{ Drought prone } & \multicolumn{3}{|c|}{ Humid moisture reliable } & \multirow[b]{2}{*}{ Pastoralist } & \multirow[b]{2}{*}{ Ethiopia } \\
\hline & Highland & Lowland & Lowland & $\begin{array}{l}\text { Highland- } \\
\text { cereal }\end{array}$ & $\begin{array}{l}\text { Highland- } \\
\text { enset }\end{array}$ & & \\
\hline \multicolumn{8}{|l|}{2035} \\
\hline P2.5 & 0.0 & -1.5 & 0.3 & 1.1 & -0.5 & -0.4 & 0.8 \\
\hline P25 & 1.2 & 0.2 & 0.3 & 1.3 & 0.6 & 0.2 & 1.2 \\
\hline Median & 1.8 & 0.5 & 0.2 & 1.3 & 1.0 & 0.9 & 1.3 \\
\hline P75 & 1.7 & 1.3 & 0.5 & 1.4 & 1.7 & 1.6 & 1.4 \\
\hline P97.5 & 2.4 & 1.6 & 0.4 & 1.7 & 2.3 & 2.8 & 1.6 \\
\hline \multicolumn{8}{|l|}{2055} \\
\hline P2.5 & -0.8 & -4.8 & 0.1 & 2.4 & -0.8 & -2.3 & 1.8 \\
\hline P25 & 2.3 & -0.4 & 0.2 & 3.0 & 1.7 & 0.0 & 2.8 \\
\hline Median & 3.2 & 0.9 & 0.3 & 3.1 & 2.3 & 1.5 & 2.9 \\
\hline P75 & 3.2 & 3.0 & 0.6 & 3.4 & 3.6 & 2.4 & 3.1 \\
\hline P97.5 & 5.1 & 3.9 & 0.7 & 4.1 & 4.9 & 5.8 & 3.8 \\
\hline \multicolumn{8}{|l|}{2085} \\
\hline P2.5 & -1.2 & -8.5 & -2.7 & 4.6 & -1.1 & -5.0 & 3.1 \\
\hline P25 & 3.9 & -0.9 & -0.8 & 5.4 & 3.8 & -0.7 & 5.2 \\
\hline Median & 5.5 & 2.8 & -0.5 & 5.7 & 5.6 & 1.9 & 5.5 \\
\hline P75 & 6.6 & 6.6 & 0.0 & 6.0 & 7.2 & 5.5 & 6.0 \\
\hline P97.5 & 9.0 & 8.7 & 0.9 & 7.3 & 9.1 & 10.5 & 6.6 \\
\hline
\end{tabular}

Source: Authors' calculations from model simulations.

Note: Percentage changes from climate model simulations. Baseline yield values were computed from observed climate data for 1960-1990 and from model projections for 2020-2039, then interpolated to 2012-2015. P2.5 $=2.5$ percentile level of climate model simulation yield results; P25 $=25$ th percentile; P75 $=75$ th percentile; and P97.5 $=97.5$ percentile.

agroecological zones in 2035 are 2.7 percent to 5.0 percent higher than average yields in the $1960-1990$ period, but only 0.6 percent to 1.5 percent higher in the two lowland agroecological zones (excluding the pastoralist zone) (Table 4.3). Median wheat yields are lower in each region, ranging from -0.3 percent in the drought-prone highlands to -1.9 percent in the droughtprone lowlands in 2035 (Table 4.4). Sorghum yields vary most across regions, with median yields in 2035 having fallen sharply by 6.2 percent due to climate change in the humid moisture-reliable lowlands but rising in all other regions by between 1.4 percent and 3.7 percent (Table 4.5). 
TABLE 4.4 Simulated climate change effects on wheat yields by agroecological zone in Ethiopia, relative to 2013 yields (\%)

\begin{tabular}{|c|c|c|c|c|c|c|c|}
\hline \multirow[b]{2}{*}{ Year } & \multicolumn{2}{|c|}{ Drought prone } & \multicolumn{3}{|c|}{ Humid moisture reliable } & \multirow[b]{2}{*}{ Pastoralist } & \multirow[b]{2}{*}{ Ethiopia } \\
\hline & Highland & Lowland & Lowland & $\begin{array}{l}\text { Highland- } \\
\text { cereal }\end{array}$ & $\begin{array}{l}\text { Highland- } \\
\text { enset }\end{array}$ & & \\
\hline \multicolumn{8}{|l|}{2035} \\
\hline P2.5 & -0.1 & -1.4 & -0.8 & -0.5 & -1.1 & -0.9 & -0.4 \\
\hline P25 & -0.2 & -1.0 & -0.6 & -0.4 & -0.6 & -0.4 & -0.3 \\
\hline Median & -0.1 & -0.7 & -0.4 & -0.3 & -0.6 & -0.6 & -0.3 \\
\hline P75 & -0.1 & -0.4 & -0.4 & -0.3 & -0.5 & -0.2 & -0.3 \\
\hline P97.5 & 0.2 & -0.2 & 0.3 & -0.1 & -0.3 & -0.2 & -0.1 \\
\hline \multicolumn{8}{|l|}{2055} \\
\hline P2.5 & -0.3 & -4.0 & -2.5 & -1.7 & -2.8 & -2.4 & -1.5 \\
\hline P25 & -0.9 & -2.5 & -1.8 & -1.4 & -2.2 & -1.4 & -1.2 \\
\hline Median & -0.6 & -1.7 & -1.1 & -1.2 & -1.8 & -1.4 & -1.2 \\
\hline P75 & -0.6 & -1.1 & -0.7 & -1.0 & -1.4 & -0.7 & -1.0 \\
\hline P97.5 & 0.2 & -0.5 & -0.8 & -0.5 & -0.9 & -0.6 & -0.4 \\
\hline \multicolumn{8}{|l|}{2085} \\
\hline P2.5 & -1.8 & -5.8 & -5.3 & -4.5 & -7.1 & -3.4 & -4.3 \\
\hline P25 & -2.5 & -4.1 & -3.9 & -3.5 & -4.9 & -2.5 & -3.2 \\
\hline Median & -2.0 & -3.1 & -2.6 & -2.8 & -3.9 & -2.3 & -2.7 \\
\hline P75 & -1.3 & -2.2 & -1.3 & -2.2 & -3.2 & -0.9 & -2.1 \\
\hline P97.5 & 0.0 & -1.3 & -0.1 & -1.1 & -1.7 & -0.5 & -1.1 \\
\hline
\end{tabular}

Source: Authors' calculations from model simulations.

Note: Percentage changes from climate model simulations. Baseline yield values were computed from observed climate data for 1960-1990 and from model projections for 2020-2039, then interpolated to 2012-2015. P2.5 = 2.5 percentile level of climate model simulation yield results; P25 $=25$ th percentile; P75 $=75$ th percentile; and P97.5 $=97.5$ percentile.

\section{Implications of Technical Change Coupled with Climate Change on Crop Yields}

Given that cereal yields in Ethiopia are considerably lower than those in most developed countries, there is substantial potential for technical change through increased use of improved seeds and fertilizer and better water management to lead to significant increases in cereal yields over time (van Ittersum et al. 2016). Maize, wheat, and sorghum yields increased by 4.6 percent, 7.2 percent, and 2.3 percent per year, respectively, over the 2010/2011-2015/2016 Ethiopian calendar years. ${ }^{10}$ Further yield increases of

10 These calculations are based on Ethiopia, Central Statistical Agency (CSA) data. Note that the Ethiopian calendar year begins and ends in mid-September. 
TABLE 4.5 Simulated climate change effects on sorghum yields by agroecological zone in Ethiopia, relative to 2013 yields (\%)

\begin{tabular}{|c|c|c|c|c|c|c|c|}
\hline \multirow[b]{2}{*}{ Year } & \multicolumn{2}{|c|}{ Drought prone } & \multicolumn{3}{|c|}{ Humid moisture reliable } & \multirow[b]{2}{*}{ Pastoralist } & \multirow[b]{2}{*}{ Ethiopia } \\
\hline & Highland & Lowland & Lowland & $\begin{array}{l}\text { Highland- } \\
\text { cereal }\end{array}$ & $\begin{array}{l}\text { Highland- } \\
\text { enset }\end{array}$ & & \\
\hline \multicolumn{8}{|l|}{2035} \\
\hline P2.5 & 0.4 & 1.0 & -3.3 & 1.3 & 0.1 & 0.6 & 0.4 \\
\hline P25 & 0.6 & 1.0 & -2.9 & 1.4 & 0.8 & 0.8 & 0.5 \\
\hline Median & 0.8 & 1.1 & -2.3 & 1.3 & 0.9 & 0.5 & 0.6 \\
\hline P75 & 0.7 & 1.3 & -1.2 & 1.4 & 1.4 & 1.1 & 0.6 \\
\hline P97.5 & 1.6 & 1.7 & -0.7 & 1.7 & 2.3 & 1.7 & 0.8 \\
\hline \multicolumn{8}{|l|}{2055} \\
\hline P2.5 & 0.1 & 1.0 & -10.1 & 2.8 & 1.3 & -0.1 & 0.4 \\
\hline P25 & 0.3 & 1.7 & -8.8 & 2.8 & 1.9 & 0.4 & 0.4 \\
\hline Median & 0.8 & 1.8 & -6.9 & 2.6 & 2.0 & 0.6 & 0.5 \\
\hline P75 & 0.5 & 2.0 & -4.9 & 2.7 & 2.5 & 1.3 & 0.7 \\
\hline P97.5 & 2.5 & 4.1 & -2.9 & 3.3 & 6.2 & 3.0 & 1.3 \\
\hline \multicolumn{8}{|l|}{2085} \\
\hline P2.5 & -4.7 & 0.4 & -25.2 & 2.8 & 1.6 & -3.7 & -3.3 \\
\hline P25 & -2.2 & 1.8 & -19.3 & 3.1 & 2.8 & -1.2 & -2.1 \\
\hline Median & -0.6 & 2.3 & -16.0 & 3.4 & 3.0 & -0.3 & -0.9 \\
\hline P75 & -0.3 & 2.8 & -12.5 & 3.8 & 3.7 & 2.1 & -0.5 \\
\hline P97.5 & 4.4 & 7.4 & -1.9 & 5.2 & 11.5 & 5.6 & 2.6 \\
\hline
\end{tabular}

Source: Authors' calculations from model simulations.

Notes: Percentage changes from climate model simulations. Baseline yield values were computed from observed climate data for 1960-1990 and from model projections for 2020-2039, then interpolated to 2012-2015. P2.5 = 2.5 percentile level of climate model simulation yield results; $\mathrm{P} 25=25$ th percentile; $\mathrm{P} 75=75$ th percentile; and P97.5 = 97.5 percentile.

this magnitude are not likely, however, so we model a much more moderate growth in yields due to technical change of 1.5 percent per year for maize and 1.0 percent per year for wheat and sorghum. Under these assumptions technical change (with no climate change) would result in a 38.8 percent increase in maize yields between 2013 and 2035; wheat and sorghum yields would each increase by 23.9 percent (see Table 4.2; Figure 4.7).

Even with these rather modest rates of yield gains from technical change, the effects of technical change are far greater than the effects of climate change, so that average yields of maize, wheat, and sorghum overall, taking into account the effects of climate change on yields, will increase by 40.5 percent, 23.5 percent, and 24.6 percent, respectively, between 2013 and 
FIGURE 4.7 Simulated yields in 2035 in Ethiopia with technical change and climate change relative to 2013 yields (\%)

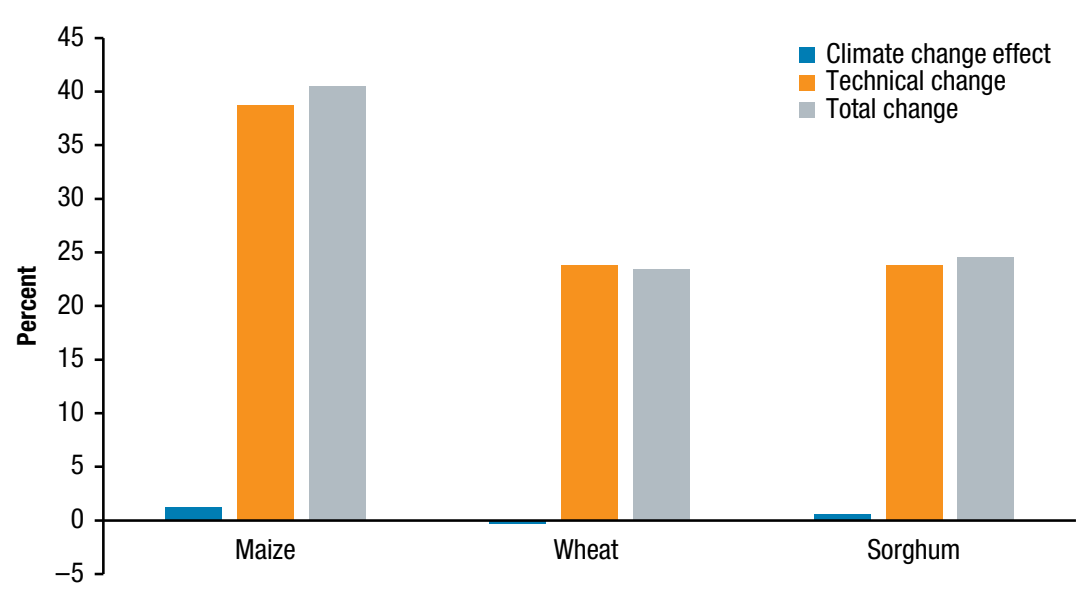

Source: Authors' calculations from model simulations.

Note: Yields estimated from percentage changes in yields from climate change model simulations.

2035 (Table 4.2; Figure 4.7). By 2055 the total yield gains would be substantially larger-91.8 percent for maize, 49.4 for wheat, and 52.0 percent for sorghum.

\section{Conclusion}

The model simulations suggest that climate change will likely have only relatively small effects on average yields of maize, wheat, and sorghum in Ethiopia in 2035 and even in 2055. Although temperatures are expected to increase, average rainfall is also expected to increase in most regions of the country. Thus agronomic conditions for cultivation of these crops may actually improve in large parts of the country, especially the highlands, that currently have moderate average temperatures.

Nonetheless, crop yields will need to increase to enable cereal production to keep pace with expected demand growth due to increases in population and per capita incomes. This in turn will require continued public and private investments in agriculture and rural infrastructure as well as policies that maintain incentives for modern input use and adoption of new technology. These investments and policies are particularly important because in many parts of the country land degradation is reducing yields, necessitating further 
investments in sustainable land management as well as increased fertilizer use to enable even moderate yield gains (Schmidt et al. 2017).

Moreover, even if future changes in climate have only moderate impacts on average crop yields in Ethiopia, there is growing evidence that weather outcomes, particularly rainfall, are likely to become more variable in the future. For example, Pendergrass et al. (2017) suggest that precipitation variability over land rises by 4 percent to 5 percent for every degree Celsius increase in temperature. Thus there could still be substantial effects on crop production and household welfare (as well as on livestock) due to extreme eventsdroughts, floods, or extremely high temperatures. And because the effects of rainfall on yield is more $U$-shaped than linear, a rise in variability, even without a shift in the mean, almost always leads to a reduction in average yields and not just yields under extreme weather. The findings presented in this chapter are no cause for complacency in Ethiopian agriculture in the face of climate change.

\section{References}

Admassu, H., G. Mezgebu, T. S. Thomas, M. Waithaka, and M. Kyotalimye. 2013. "Ethiopia.” In East African Agriculture and Climate Change: A Comprehensive Analysis, edited by M. Waithaka, G. C. Nelson, T. S. Thomas, and M. Kyotalimye, 149-182. Washington, DC: International Food Policy Research Institute (IFPRI).

Collins, W., N. Bellouin, M. Doutriaux-Boucher, N. Gedney, P. Halloran, T. Hinton, J. Hughes, et al. 2011. "Development and Evaluation of an Earth-System Model-HadGEM2." Geoscience Model Development 4 (4): 1051-1075.

Dile, Y. T., R. Berndtsson, and S. G. Setegn. 2013. "Hydrological Response to Climate Change for Gilgel Abay River, in the Lake Tana Basin-Upper Blue Nile Basin of Ethiopia." PLoS ONE 8 (10): e79296.

FAO (Food and Agriculture Organization of the United Nations). 2019. FAOSTAT database. Accessed January 24, 2019. www.fao.org/faostat/en/.

Hijmans, R. J., S. E. Cameron, J. L. Parra, P. G. Jones, and A. Jarvis. 2005. “Very High Resolution Interpolated Climate Surfaces for Global Land Areas." International Journal of Climatology: A Journal of the Royal Meteorological Society 25 (15): 1965-1978.

Hoogenboom, G., J. W. Jones, P. W. Wilkens, C. H. Porter, K. J. Boote, L. A. Hunt, U. Singh, et al. 2012. Decision Support System for Agrotechnology Transfer (DSSAT). Version 4.5. Honolulu: University of Hawaii, Honolulu. CD-ROM. 
IPCC (Intergovernmental Panel on Climate Change). 2018. Global Warming of 1.5 ${ }^{\circ}$. An IPCC Special Report on the Impacts of Global Warming of $1.5^{\circ} \mathrm{C}$ above Pre-Industrial Levels and Related Global Greenhouse Gas Emission Pathways, in the Context of Strengthening the Global Response to the Threat of Climate Change, Sustainable Development, and Efforts to Eradicate Poverty. Geneva, Switzerland: World Meteorological Organization.

Jones, J. W., G. Hoogenboom, C. H. Porter, K. J. Boote, W. D. Batchelor, L. A. Hunt, P. W. Wilkens, U. Singh, A. J. Gijsman, and J. T. Ritchie. 2003. “The DSSAT Cropping System Model." European Journal of Agronomy 18 (3-4): 235-265.

Kim, U., and J. J. Kaluarachchi. 2009. "Climate Change Impacts on Water Resources in the Upper Blue Nile River Basin, Ethiopia." Journal of the American Water Resource Association 45 (6): 1361-1378.

Kim, U., J. J. Kaluarachchi, and V. U. Smakhtin. 2008. Climate Change Impacts on Hydrology and Water Resources of the Upper Blue Nile River Basin, Ethiopia. International Water Management Institute (IWMI) Research Report 126. Colombo, Sri Lanka: IWMI.

Martin, G., N. Bellouin, W. Collins, I. Culverwell, P. Halloran, S. Hardiman, and T. Hinton. 2011. "The HadGEM2 Family of Met Office Unified Model Climate Configurations." Geophysical Model Development 4: 723-757.

Nawaz, R., T. Bellerby, M. Sayed, and M. Elshamy. 2010. "Blue Nile Runoff Sensitivity to Climate Change." Open Hydrology Journal 4: 137-151.

Pendergrass, A. G., R. Knutti, F. Lehner, C. Deser, and B. M. Sanderson. 2017. “Precipitation Variability Increases in a Warmer Climate.” Scientific Reports 7: 17966.

Ramirez, J., and A. Jarvis. 2008. High Resolution Statistically Downscaled Future Climate Surfaces. Cali, Colombia: International Center for Tropical Agriculture: CGIAR Research Program on Climate Change, Agriculture and Food Security (CCAFS).

Ramirez-Villegas, J., and A. Jarvis. 2010. Downscaling Global Circulation Model Outputs: The Delta Method. Decision and Policy Analysis Working Paper 1. Cali, Colombia: International Center for Tropical Agriculture.

Robinson, S., D. Willenbockel, and K. Strzepek. 2012. "A Dynamic General Equilibrium Analysis of Adaptation to Climate Change in Ethiopia." Review of Development Economics 16 (3): 489-502.

Ruane, A. C., R. Goldberg, and J. Chryssanthacopoulos. 2015. “Climate Forcing Datasets for Agricultural Modeling: Merged Products for Gap-Filling and Historical Climate Series Estimation." Agricultural and Forest Meteorology 200: 233-248.

Schmidt, E., P. Chinowsky, S. Robinson, and K. Strzepek. 2017. "Determinants and Impact of Sustainable Land Management (SLM) Investments: A Systems Evaluation in the Blue Nile Basin, Ethiopia." Agricultural Economics 48 (5): 613-627. 
Schmidt, E., and T. S. Thomas. 2018. Cropland Expansion in Ethiopia: Economic and Climatic Considerations for Highland Agriculture. Ethiopia Strategy Support Program (ESSP) Working Paper 127. Addis Ababa: IFPRI.

Taye, T. M., P. Willems, and P. Block. 2015. "Implications of Climate Change on Hydrological Extremes in the Blue Nile Basin: A Review." Journal of Hydrology: Regional Studies 4 (B): 280-293.

van Ittersum, M. K., L. G. J. van Bussel, J. Wolf, P. Grassini, J. van Wart, N. Guilpart, L. Claessens, et al. 2016. "Can Sub-Saharan Africa Feed Itself?" Proceedings of the National Academy of Sciences of the United States of America 113 (52): 14964-14969.

Wagena, M. B., A. Sommerlot, A. Z. Abiy, A. S. Collick, S. Langan, D. R. Fuka, and Z. M. Easton. 2016. "Climate Change in the Blue Nile Basin Ethiopia: Implications for Water Resources and Sediment Transport." Climatic Change 139: 229-243.

WorldClim Version 1.4. 2019. Climate data. Accessed January 24, 2019. www.worldclim.org/.

You, L., S. Wood, and U. Wood-Sichra. 2006. "Generating Global Crop Maps: From Census to Grid." Selected paper presentation at the International Association of Agricultural Economists annual conference, Gold Coast, Australia, August 12-18.

You, L., U. Wood-Sichra, S. Fritz, Z. Guo, L. See, and J. Koo. 2014. "Spatial Production Allocation Model (SPAM) 2005 v2.0.” Accessed January 24, 2019. http://mapspam.info. 
